\title{
Political Regime Change, EcOnOMiC REFORM AND GROWTH ACCELERATIONS
}

\author{
RICHARD JONG-A-PIN \\ JAKOB DE HAAN
}

\section{CESIFO WORKING PAPER NO. 1905}

Category 5: Fiscal Policy, Macroeconomics and Growth JANUARY 2007

An electronic version of the paper may be downloaded

- from the SSRN website:

- from the RePEc website:

- from the CESifo website:

www.SSRN.com

Www.RePEc.org

www.CESifo-group.de 


\title{
POLITICAL REGIME CHANGE, ECONOMIC REFORM AND GROWTH ACCELERATIONS
}

\begin{abstract}
Using an improved definition and indicator of growth accelerations, we examine whether political regimes, regime changes, and economic reform are related to growth accelerations. Our results show that economic growth accelerations are preceded by economic reforms. Furthermore, we find that growth accelerations are more likely to happen after the start of a new political regime.
\end{abstract}

JEL Code: O17, O11.

Keywords: economic growth, growth accelerations, regime changes, economic reform.

Richard Jong-A-Pin

Faculty of Economics

University of Groningen

PO Box 800

9700 AV Groningen

The Netherlands

r.m.jong.a.pin@rug.nl
Jakob De Haan

Faculty of Economics

University of Groningen

PO Box 800

9700 AV Groningen

The Netherlands

jakob.de.haan@rug.nl

Version, 8 January 2007 


\section{Introduction}

Various studies suggest that economic reform and the political regime in place are driving a country's economic growth performance. ${ }^{1}$ However, models testing these relationships have been criticized for their limited ability to address causality (e.g. Durlauf, Johnson and Temple, 2005). Furthermore, cross-country growth regressions are based on very strong assumptions about a single linear model being appropriate for all countries in all states, while very few countries have experienced consistently constant growth rates over periods of several decades. Therefore, Hausmann, Pritchett and Rodrik (2005) focus on so-called growth accelerations and examine which covariates are related to periods of rapid economic growth. ${ }^{2}$ They find that growth accelerations are often preceded by political regime changes, while economic reform is hardly related to these accelerations. $^{3}$

In this paper we re-examine the relationship between economic reform, political regime changes, and growth accelerations, making the following contributions. First, we improve upon the filter used by Hausmann et al. to identify growth accelerations as this filter yields some strange outcomes. For example, 27 episodes identified as accelerations have higher growth in the year before the acceleration than at the start of the acceleration. Second, we find that country fixed effects should not be neglected when examining growth accelerations. Therefore, we use conditional fixed effects logistic regressions as proposed by Chamberlain (1980) instead of (pooled) probit regressions. Third, we do not only focus on (the direction of) regime changes, but also examine the role of regime duration. Finally, we do not solely rely on the Polity IV dataset, but also investigate the robustness of our results using alternative regime indicators.

Our main findings are that that economic growth accelerations are preceded by economic reforms. Furthermore, we find that growth accelerations are more likely to happen after the start of a new political regime.

\footnotetext{
${ }^{1}$ For a survey on the relationship between economic growth and political regimes see e.g. Przeworski, Alvarez, Cheibub and Limongi (2000). Winters (2004) provides an overview of the relationship between trade liberalization and economic growth, while the literature on economic reform and economic growth is surveyed by De Haan, Lundström and Sturm (2006).

${ }^{2}$ Related papers that organise the data around particular events to identify causal determinants of growth include Jones and Olken (2005a, b).

${ }^{3}$ However, Jong-A-Pin and De Haan (2006) argue that these results are driven by an error in the dataset of Hausmann et al. and find that regime changes are not related to growth accelerations.
} 
The paper proceeds as follows. Section 2 discusses our filter to identify economic growth accelerations. Section 3 analyzes the relationship between political regime changes, economic reform and growth accelerations, while section 4 examines the robustness of our results. Section 5 concludes.

\section{Identifying growth accelerations}

For the period 1957-1992, Hausmann et al. (2005) identify no less than 83 periods of accelerated growth, using the following filter. For each country (with more than 1 million inhabitants and more than 20 available observations), the logarithm of real GDP per capita (taken from the Penn World Tables 6.2.) is regressed on time for every eight year period $(\mathrm{n}=7)$. That is,

$$
\ln \left(y_{t+i}\right)=a+g_{t, t+n} * t+\varepsilon, \quad i=0, \cdots, n
$$

Where $y$ denotes real GDP capita and $t$ is time. The estimated parameter, $g_{t, t+n}$, is taken as a proxy for the average growth rate over the period $t$ to $t+n$ and labeled the "least squares growth rate”. To qualify as a growth acceleration, the least squares growth rate should be at least 3.5\% per annum. Furthermore, it should be at least 2 percentage points higher than in the previous eight years. Finally, to rule out episodes of full economic recovery, the level of real GDP should be higher at the end of the acceleration than in all years before the acceleration. In cases that consecutive years qualify to be the start of a growth acceleration, the year is chosen with the highest F-statistic of a piecewise linear (or spline) regression with the break at the relevant year. Hausmann et al. allow for the possibility that an acceleration is followed by another acceleration as long as the second acceleration starts at least five years after the first one.

Hausmann et al. (2005) provide several robustness checks to convince the reader that the chosen criteria are defensible. Still, we argue that these criteria can be improved upon. Table 1 reports the growth rate before the start of the growth accelerations identified by Hausmann et al, the growth rate in the first year of the acceleration and the eight year growth average according to data from the Penn World Tables 6.2. 
[Table 1 here]

It follows that 18 growth acceleration episodes as identified by Hausmann et al. have a negative growth rate in the first year of the acceleration. Furthermore, 27 of the identified episodes have a higher growth rate in the year before the acceleration than at the start of the acceleration. Finally, in 10 episodes, growth in the year before the acceleration is higher than the average growth rate during the entire acceleration. On the basis of these figures it seems that episodes falling in the first category are identified too early, while episodes falling in the latter categories are identified too late. ${ }^{4}$

To identify the initiation of a growth acceleration adequately, we propose a simple criterion that first identifies all possible take-offs of an acceleration. This criterion is similar to the so-called BBQ rule used to identify turning points in business cycles (Harding and Pagan, 2002). To qualify as the start of an economic growth acceleration in year $t$, growth should be higher than in the year before ${ }^{5}$ :

$$
g_{t+1}>g_{t}
$$

If year $t$ fulfills this criterion, we check whether it also fulfills the three criteria of Hausmann et al. (2005):

$$
\begin{aligned}
& g_{t, n+7}>3.5 p p a \\
& g_{t, n+7}-g_{t-7, t}>2.0 p p a \\
& y_{t+7}>\max \left\{y_{i}\right\} \quad i \leq t
\end{aligned}
$$

If these are satisfied as well and year $t-1$ and year $t+1$ do not qualify, year $t$ is the start of the growth acceleration. If consecutive years fulfill all criteria, we take the year in which the level of real GDP is minimal to be the starting point of the growth acceleration. This

\footnotetext{
${ }^{4}$ In our opinion, the reason why the filter is unable to identify the start of the growth acceleration adequately is the use of the spline regression method. If one break is allowed in the fitted function, its optimal position is also affected by the volatility and other breaks in the series. As a consequence, the criterion of the highest F-statistic of the fitted function gives the best fitted line through the GDP series, but not necessarily the optimal location of the break.

${ }^{5}$ As a robustness check, we also examined the criterion that the two-year growth rate should exceed the two-year growth rate before the start of the growth acceleration. This alternative criterion ensures that the growth rate at the start of the acceleration is substantial.
} 
simple rule ensures that the growth rate in the first year of an acceleration always increases relative to the previous year. Our filter identifies 84 accelerations, which are reported in Table $2 .^{6}$

[Table 2 here]

There are substantial differences between accelerations based on the filter of Hausmann et al. (2005) and those based on our filter. Only 28 episodes (33\%) are identified at exactly the same date, 31 episodes (37\%) differ one year, while 15 episodes (18\%) are identified with more than one year difference. Furthermore, our filter does not pick up 9 episodes, which are identified by the filter of Hausmann et al. as these episodes do not fulfill the condition that the growth rate at the first year of the acceleration should be larger than the growth rate in the year before the acceleration. ${ }^{7}$ Finally, we identify 10 episodes not found by Hausmann et al..

To illustrate the different results, Figure 1 shows the real GDP series of Chile, Botswana and Mali.

[Figure 1 here]

The figure indicates in which year the growth acceleration starts according to both approaches. It can be seen that in the case of Chile, the timing of the filter of Hausmann et al. is too late, while it is too early in the case of Botswana. The case of Mali illustrates that the acceleration identified by Hausmann et al. in fact lasts only 6 years. However, it is identified as an acceleration, because the average growth rate in the last 6 years of the acceleration compensate for the negative growth rate in the first two years of the

\footnotetext{
${ }^{6}$ We checked whether our episodes suffer from the same problem as dealt with in Table 1 . In turns out that on two occasions our filter identifies an acceleration which is preceded by a year that has a higher growth rate than the average growth rate during the entire acceleration: Congo (1969) and Pakistan (1965). In the case of Congo, the actual growth acceleration started before the sample period, i.e. 1967. The situation of Pakistan is different as 1965 is the first possible start after the previous acceleration.

7 These episodes are (starting year in parenthesis): Guinea-Bissau (1988), Haiti (1990), Malawi (1992), Mali (1972), Papua New Guinea (1987), Poland (1992), Syria (1974), Uganda (1977) and Uruguay (1989).
} 
acceleration. As it is required that the acceleration has to be (at least) 8 years, our rule makes sure that these quasi growth accelerations are not identified.

\section{Empirical Analysis}

We examine which variables trigger the start of a growth acceleration. In particular, we are interested in the effect of economic reform and political regime changes. The dependent variable we employ in the analysis takes a value of one centered on the timing of the start of a growth acceleration and zero otherwise. ${ }^{8}$ Our dataset consists of 106 countries over the period 1957-1993 of which 57 countries experienced at least one growth acceleration.

As a proxy for economic reform we rely on the index provided by Wacziarg and Welch (2003), that incorporates a number of structural features (e.g., presence of marketing boards and socialist economic regimes) and the macroeconomic environment (e.g., presence of a large black-market premium for foreign currency), in addition to tariff and non-tariff barriers to trade. Following Hausmann et al. (2005), the variable included is a dummy that takes the value of 1 during the first five years of a transition towards “openness".

Our regime change variable is taken from the Polity IV dataset of Marshall and Jaggers (2002). A regime change is defined as a three points change in the Polity score in three years or less. However, as it is possible that a country has no formal regime for a couple of years, we focus only on those changes, which are followed by a continuation of the same regime for at least one year. Like the economic reform dummy, we use a dummy equal to one for the first five years after a political regime change and zero otherwise. Following Hausmann et al. (2005), we differentiate between positive (i.e. changes towards more democracy) and negative regime changes (changes towards more autocracy). In addition, we add the durability of a regime defined as the number of years

\footnotetext{
${ }^{8}$ We follow Hausmann et al. regarding the treatment of the dependent variable. That is, if an acceleration starts in year $t$ then year $t-1$ and $t+1$ also are assigned the value one. As shown in the previous section, there is some uncertainty concerning the timing of a growth acceleration and following the approach of Hausmann et al. reduces the probability of missing the initiation of an acceleration. Furthermore, we omit those observations from the analysis which cannot be the start of the acceleration (years $t+2-t+5$ ).
} 
that the current regime is in place, following the suggestion of Clague, Keefer, Knack and Olson (1996). ${ }^{9}$

We test for the appropriate panel data model using the Hausman test (Hausman, 1978). We test the null-hypothesis that all country fixed effects equal zero by comparing the estimates of a conditional fixed effects logit (CFEL) model (see Chamberlain, 1980) and the unrestricted (pooled) logit model. The null-hypothesis of no country specific effects is rejected for all model specifications. Hence, CFEL should be preferred. Furthermore, we examine the presence of time effects in the dataset. Figure 2 shows the average number of growth accelerations per year for the entire sample period. The pattern we roughly observe is that the number of growth accelerations is steadily decreasing over time. Therefore, we include a linear trend in our model, which turns out to be highly significant in all specifications.

[Figure 2 here]

Table 3 contains the estimation results. The results reported in columns 1-4 are based on the full sample, while columns 5-8 excludes those episodes that started just after an economic crisis. As it seems likely that economic growth picks up after a crisis, we want to make sure that our results are not driven by the inclusion of this kind of 'economic recovery' accelerations. In case the growth rate in the two years before the growth acceleration is smaller than $-10 \%$ we define it as a post-crises growth acceleration. ${ }^{10}$

[Table 3 here]

It can be immediately observed that the results for the two samples are very similar. In contrast to the results reported by Hausmann et al. (2005), we find that the effect of economic reform on the probability of a growth acceleration is highly significant in all specifications. However, the results for political regime changes are less clear. Political regime changes are in general not related to growth accelerations, but we do find a

\footnotetext{
${ }^{9}$ The correlation coefficient between our regime change dummy and the durability indicator is -0.37 .

${ }^{10}$ Using a threshold of $-5 \%$ results in exactly the same result (14 post crisis growth accelerations). If a threshold of $-15 \%$ is used, we find only 3 such episodes.
} 
negative and significant effect of regime duration for all specifications. This implies that growth accelerations are more likely to happen after the start of a new political regime. Although the results seems to contradict each other, we think this can be explained by the fact that our regime change dummy only takes the value of one in the first five years after a regime change. It can therefore be concluded that for a growth acceleration to happen, it may take more than five years after a political regime change.

If we differentiate between regime changes towards more democracy and changes towards more autocracy, we find that regime changes are only marginally related to the initiation of a growth acceleration. The point estimates, however, suggest that growth accelerations are more likely to happen in the first five year after a change towards more autocracy than a change towards more democracy.

\section{Robustness analysis}

To check the robustness of our results we run several variants of our base model. The results are reported in Table $4 .{ }^{11}$

[Table 4 here]

First, we replace the regime change variable for two alternative indicators. These alternative indicators are based on Prezworski et al. (2000) and Vanhanen (2000). We define a regime change if according to these authors the regime switches from democracy to autocracy and vice versa. According to both measures, a change to more autocracy significantly increases the probability of a growth acceleration. A change to more democracy is marginally related to growth accelerations according to the indicator of Vanhanen.

Next, we examine the robustness of our results using a variant of our filter. Instead of the rule that in the first year of the acceleration the growth rate has to be higher than in the year before the acceleration, we now restrict the filter to identify those take-

\footnotetext{
${ }^{11}$ The results presented here are based on the sample including all episodes. We also checked whether the results differ if we exclude accelerations after an economic crisis. These results are very similar to the results presented here and are available on request.
} 
offs in which the two-year growth rate is higher than the two-year growth rate before the start of the acceleration. Again, the results are very similar to those presented in the baseline model.

Finally, we add several control variables to the baseline model. These variables are also used by Hausmann et al. (2005). In column 6 we incorporate terms of trade, whilst we add a dummy for financial liberalization in column 7. Unfortunately, the use of additional control variables decreases the sample size. It can be seen that adding the terms of trade variable or the financial liberalization measure affects the result for the economic reform variable, which becomes insignificant. This result is driven by the fact that a number of countries drop from the sample, which had an economic reform just before a growth acceleration. ${ }^{12}$

When we include variables that capture characteristics of the political environment such as the tenure and death of a political leader (following Jones and Olken (2005b)), or the presence (or end of) a civil war, we obtain the same results as in the baseline model.

\section{Concluding comments}

Due to the fixation on long-run differences in growth, empirical growth research has underestimated the importance of instability and volatility in growth rates, especially in developing countries. Traditional cross-country and panel growth models are not well suited to use information provided by the time dimension. Periods chosen in panel models are often justified only on the grounds that data were available at those frequencies or the researcher wanted to divide the whole period into equal chunks. These periods are unlikely to identify information provided by the development of variables over time. If, for instance, there is a high growth rate in the first five years and a low growth rate in the second half of the ten year period, the period average will be rather uninformative.

\footnotetext{
${ }^{12}$ In fact, the four countries that drop from the sample if we include financial liberalisation all had an economic reform just before the start of the acceleration, i.e. Denmark, Tunisia, Taiwan and Uganda.
} 
The approach suggested by Hausman et al. (2005) is much more promising to use the information provided by the time dimension. These authors focus on turning points in growth performance, examining instances of rapid acceleration in economic growth that are sustained. They identify more than 80 such episodes since the 1950 s, finding that political-regime changes are statistically significant predictors of growth accelerations.

Building upon the work by Hausman et al., we make various contributions. First, we improve upon the filter used by Hausmann et al. to identify growth accelerations as their filter yields some strange outcomes. Second, we test for country fixed effects and based on the testing outcomes use conditional fixed effects logistic regressions as proposed by Chamberlain (1980) instead of (pooled) probit regressions. Third, we do not only focus on (the direction of) regime changes, but also examine the role of regime duration. Finally, we investigate the robustness of our results using alternative regime indicators.

Our main findings differ from those of Hausmann et al. (2005). First, we find that economic growth accelerations are preceded by economic reforms. Furthermore, our results suggest the impact of political regimes changes is not robust, but that growth accelerations are more likely to happen after the start of a new political regime. 


\section{References}

Alvarez, M., Cheibub, J.A., Limongi, F. and Przeworski. A. (1996). "Classifying Political Regimes”, Studies in Comparative International Development, 31:3-34.

Chamberlain, G. (1980), Analysis of covariance with qualitative data, Review of Economic Studies, 47: 225-238.

Cheibub, J. A. and Gandhi, J. (2004), "Classifying Political Regimes: A Six-Fold Measure of Democracies and Dictatorships”, Paper prepared for the Annual Meeting of the American Political Science Association, Chicago, September 2004.

Clague, C., Keefer, P., Knack, S. and Olson, M. (1996), "Property and contract rights in autocracies and democracies”, Journal of Economic Growth, 1: 243-276.

De Haan, J., Lundström, S. and J.E. Sturm, (2006), "Market-oriented institutions and policies and economic growth: A critical survey", Journal of Economic Surveys, 20: 157-191.

Durlauf, S., Johnson, P. and J. Temple (2004). "Growth Econometrics," in Aghion, P. and Durlauf S. (eds), Handbook of Economic Growth, chapter 8: 555-677, Amsterdam: Elsevier.

Harding, D. and A. R. Pagan, (2002), “Dissecting the Cycle: A Methodological Investigation”, Journal of Monetary Economics, 49, 365-381.

Hausman, J. (1978), “Specification tests in econometrics”, Econometrica, 46: 1251-1271.

Hausmann, R., Pritchett, L. and Rodrik, D. (2005). “Growth accelerations”, Journal of Economic Growth, 10, 303-329.

Jones, B. F. and B.A. Olken, (2005a), “The Anatomy of Start-Stop Growth”, NBER Working Paper, No. 11528.

Jones, B.F. and B.A Olken. (2005b), “Do Leaders Matter? National Leadership and Growth Since World War II”, Quarterly Journal of Economics, 120(3): 835-64.

Jong-A-Pin, R.M. and J. De Haan, (2006), "Growth accelerations: a comment", University of Groningen, mimeo. 
Przeworski, A., Alvarez, M., Cheibub, J. A. and Limongi, F. (2000), “Democracy and Development: Political Regimes and Economic Well-being in the World", 1950-1990, New York: Cambridge University Press.

Marshall, M.G. and K. Jaggers. (2002). Polity IV Data Set. [Computer file; version p4v2002] College Park, MD: Center for International Development and Conflict Management, University of Maryland.

Vanhanen, T. (2000), “A New Dataset for Measuring Democracy, 1810-1998”, Journal of Peace Research, 37: 251-265.

Wacziarg, R., and K. H. Welch. (2003). “Trade Liberalization and Growth: New Evidence,” Stanford University, mimeo.

Winters, L.A. (2004), “Trade Liberalisation and Economic Performance: An Overview”, The Economic Journal, 114 (493): F4-F21. 
Table 1. Growth accelerations according to Hausmann et al. (2005)

\begin{tabular}{|c|c|c|c|c|c|c|c|}
\hline Country & $\begin{array}{l}\text { (1) } \\
\text { Year }\end{array}$ & $\begin{array}{c}(2) \\
\text { Growth in } \\
\text { year before } \\
\text { acceleration }\end{array}$ & $\begin{array}{c}\text { (3) } \\
\text { Growth at } \\
\text { start } \\
\text { acceleration }\end{array}$ & $\begin{array}{l}\text { Average } \\
\text { growth } \\
\text { during } \\
\text { acceleration }\end{array}$ & $\begin{array}{c}\text { Growth } \\
\text { before }> \\
\text { growth at } \\
\text { start? }\end{array}$ & $\begin{array}{c}\text { (6) } \\
\text { Growth } \\
\text { before>growth } \\
\text { during? }\end{array}$ & $\begin{array}{l}(7) \\
\text { Growth } \\
\text { at start } \\
<0 ?\end{array}$ \\
\hline Algeria & 1975 & 1.6 & 10.7 & 4.2 & $\mathrm{n}$ & $\mathrm{n}$ & $\mathrm{n}$ \\
\hline Argentina & 1963 & -6.1 & 7.7 & 3.6 & $\mathrm{n}$ & $\mathrm{n}$ & $\mathrm{n}$ \\
\hline Argentina & 1990 & -6.0 & 9.8 & 6.1 & $\mathrm{n}$ & $\mathrm{n}$ & $\mathrm{n}$ \\
\hline Australia & 1961 & -1.7 & 4.8 & 3.8 & $\mathrm{n}$ & $\mathrm{n}$ & $\mathrm{n}$ \\
\hline Belgium & 1959 & 3.8 & 5.4 & 4.5 & $\mathrm{n}$ & $\mathrm{n}$ & $\mathrm{n}$ \\
\hline Botswana & 1969 & 5.1 & -5.1 & 11.7 & $y$ & $\mathrm{n}$ & $y$ \\
\hline Brazil & 1967 & 2.5 & 8.4 & 7.8 & $\mathrm{n}$ & $\mathrm{n}$ & $\mathrm{n}$ \\
\hline Canada & 1962 & 5.1 & 3.4 & 3.6 & $y$ & $y$ & $\mathrm{n}$ \\
\hline Chad & 1973 & -8.3 & -4.6 & 7.3 & $\mathrm{n}$ & $\mathrm{n}$ & $y$ \\
\hline Chile & 1986 & 3.1 & 3.7 & 5.5 & $\mathrm{n}$ & $\mathrm{n}$ & $\mathrm{n}$ \\
\hline China & 1978 & -1.1 & 10.6 & 6.7 & $\mathrm{n}$ & $\mathrm{n}$ & $\mathrm{n}$ \\
\hline China & 1990 & 7.0 & 10.6 & 8.0 & $\mathrm{n}$ & $\mathrm{n}$ & $\mathrm{n}$ \\
\hline Colombia & 1967 & 0.8 & 2.9 & 4.0 & $\mathrm{n}$ & $\mathrm{n}$ & $\mathrm{n}$ \\
\hline Comoros & 1972 & -2.8 & 0.6 & 5.3 & $\mathrm{n}$ & $\mathrm{n}$ & $\mathrm{n}$ \\
\hline Congo Rep. & 1969 & 9.0 & 12.2 & 5.4 & $\mathrm{n}$ & $y$ & $\mathrm{n}$ \\
\hline Congo Rep. & 1978 & 7.9 & 13.7 & 8.2 & $\mathrm{n}$ & $\mathrm{n}$ & $\mathrm{n}$ \\
\hline Denmark & 1957 & 4.0 & 0.5 & 5.3 & $y$ & $\mathrm{n}$ & $\mathrm{n}$ \\
\hline Dominican Rep. & 1969 & 5.4 & 13.3 & 5.5 & $\mathrm{n}$ & $\mathrm{n}$ & $\mathrm{n}$ \\
\hline Dominican Rep. & 1992 & 4.2 & 3.8 & 6.3 & $y$ & $\mathrm{n}$ & $\mathrm{n}$ \\
\hline Ecuador & 1970 & 4.2 & 2.9 & 8.4 & $y$ & $\mathrm{n}$ & $\mathrm{n}$ \\
\hline Egypt & 1976 & 10.3 & 9.8 & 4.7 & $y$ & $y$ & $\mathrm{n}$ \\
\hline Finland & 1958 & -2.1 & 7.1 & 5.0 & $\mathrm{n}$ & $\mathrm{n}$ & $\mathrm{n}$ \\
\hline Finland & 1967 & 1.3 & 0.6 & 5.6 & $y$ & $\mathrm{n}$ & $\mathrm{n}$ \\
\hline Finland & 1992 & -7.8 & -4.3 & 2.8 & $\mathrm{n}$ & $\mathrm{n}$ & $y$ \\
\hline Ghana & 1965 & -21.7 & 22.7 & 8.3 & $\mathrm{n}$ & $\mathrm{n}$ & $\mathrm{n}$ \\
\hline Guinea-Bissau & 1969 & -1.7 & -27.8 & 8.1 & $y$ & $\mathrm{n}$ & $y$ \\
\hline Guinea-Bissau & 1988 & -5.4 & -1.6 & 5.2 & $\mathrm{n}$ & $\mathrm{n}$ & $y$ \\
\hline Haiti & 1990 & 1.9 & 11.6 & 12.7 & $\mathrm{n}$ & $\mathrm{n}$ & $n$ \\
\hline India & 1982 & 3.2 & 5.3 & 3.9 & $\mathrm{n}$ & $\mathrm{n}$ & $\mathrm{n}$ \\
\hline Indonesia & 1967 & -1.6 & 9.4 & 5.5 & $\mathrm{n}$ & $\mathrm{n}$ & $\mathrm{n}$ \\
\hline Indonesia & 1987 & 2.5 & 4.0 & 5.5 & $\mathrm{n}$ & $\mathrm{n}$ & $\mathrm{n}$ \\
\hline Ireland & 1958 & 0.0 & 4.8 & 3.7 & $\mathrm{n}$ & $\mathrm{n}$ & $\mathrm{n}$ \\
\hline Ireland & 1985 & 2.5 & -0.6 & 5.0 & $y$ & $\mathrm{n}$ & $y$ \\
\hline Israel & 1957 & 3.6 & 3.2 & 5.3 & $y$ & $\mathrm{n}$ & $\mathrm{n}$ \\
\hline Israel & 1967 & -6.0 & 17.2 & 7.2 & $\mathrm{n}$ & $\mathrm{n}$ & $\mathrm{n}$ \\
\hline Japan & 1958 & 3.4 & 8.4 & 9.0 & $\mathrm{n}$ & $\mathrm{n}$ & $\mathrm{n}$ \\
\hline Jordan & 1973 & -1.5 & -1.7 & 9.1 & $y$ & $\mathrm{n}$ & $y$ \\
\hline Rep. Korea & 1962 & -0.4 & 8.9 & 6.9 & $\mathrm{n}$ & $\mathrm{n}$ & $\mathrm{n}$ \\
\hline Rep. Korea & 1984 & 7.2 & 5.3 & 8.0 & $y$ & $\mathrm{n}$ & $\mathrm{n}$ \\
\hline Lesotho & 1971 & 3.4 & -0.6 & 5.3 & $y$ & $\mathrm{n}$ & $y$ \\
\hline Malawi & 1970 & -9.1 & 21.8 & 3.9 & $\mathrm{n}$ & $\mathrm{n}$ & $\mathrm{n}$ \\
\hline Malawi & 1992 & -10.3 & 12.8 & 4.8 & $\mathrm{n}$ & $\mathrm{n}$ & $\mathrm{n}$ \\
\hline Malaysia & 1970 & 3.3 & 3.2 & 5.1 & $y$ & $\mathrm{n}$ & $\mathrm{n}$ \\
\hline Malaysia & 1988 & 6.2 & 6.4 & 5.7 & $\mathrm{n}$ & $y$ & $\mathrm{n}$ \\
\hline
\end{tabular}




\begin{tabular}{|c|c|c|c|c|c|c|c|}
\hline Mali & 1972 & 2.8 & -3.6 & 3.8 & $y$ & $\mathrm{n}$ & $\mathrm{y}$ \\
\hline Mauritius & 1971 & -0.5 & 4.4 & 6.7 & $n$ & $\mathrm{n}$ & $\mathrm{n}$ \\
\hline Mauritius & 1983 & -0.2 & 2.6 & 5.5 & $\mathrm{n}$ & $\mathrm{n}$ & $\mathrm{n}$ \\
\hline Morocco & 1958 & 5.4 & 1.3 & 7.7 & $y$ & $\mathrm{n}$ & $\mathrm{n}$ \\
\hline New Zealand & 1957 & 3.4 & -1.3 & 3.8 & $y$ & $\mathrm{n}$ & $\mathrm{y}$ \\
\hline Nicaragua & 1960 & 6.3 & 3.6 & 4.8 & $y$ & $y$ & $\mathrm{n}$ \\
\hline Nigeria & 1957 & -0.6 & 4.2 & 4.3 & $\mathrm{n}$ & $n$ & $\mathrm{n}$ \\
\hline Nigeria & 1967 & -17.8 & -3.2 & 7.3 & $\mathrm{n}$ & $\mathrm{n}$ & $\mathrm{y}$ \\
\hline Norway & 1991 & 2.5 & 2.5 & 3.7 & $\mathrm{n}$ & $\mathrm{n}$ & $\mathrm{n}$ \\
\hline Pakistan & 1962 & 1.7 & 4.0 & 4.8 & $\mathrm{n}$ & $\mathrm{n}$ & $\mathrm{n}$ \\
\hline Pakistan & 1979 & -1.7 & 7.3 & 4.6 & $\mathrm{n}$ & $\mathrm{n}$ & $\mathrm{n}$ \\
\hline Panama & 1959 & -0.7 & 9.7 & 5.4 & $\mathrm{n}$ & $\mathrm{n}$ & $\mathrm{n}$ \\
\hline $\begin{array}{l}\text { Panama } \\
\text { Papua New }\end{array}$ & 1975 & 1.2 & -0.6 & 5.3 & $y$ & $\mathrm{n}$ & $y$ \\
\hline Guinea & 1987 & 0.0 & -4.1 & 4.0 & $\mathrm{y}$ & $\mathrm{n}$ & $\mathrm{y}$ \\
\hline Paraguay & 1974 & 3.9 & 4.3 & 6.2 & $\mathrm{n}$ & $\mathrm{n}$ & $\mathrm{n}$ \\
\hline Peru & 1959 & -6.0 & 10.6 & 5.2 & $n$ & $\mathrm{n}$ & $\mathrm{n}$ \\
\hline Poland & 1992 & 1.9 & 3.5 & 5.0 & $\mathrm{n}$ & $\mathrm{n}$ & $\mathrm{n}$ \\
\hline Portugal & 1985 & 2.7 & 4.3 & 5.4 & $n$ & $\mathrm{n}$ & $\mathrm{n}$ \\
\hline Romania & 1979 & 6.5 & -2.1 & 12.4 & $y$ & $\mathrm{n}$ & $y$ \\
\hline Rwanda & 1975 & -2.1 & 15.1 & 4.0 & $\mathrm{n}$ & $\mathrm{n}$ & $n$ \\
\hline Singapore & 1969 & 12.5 & 12.3 & 8.2 & $y$ & $y$ & $\mathrm{n}$ \\
\hline Spain & 1959 & -4.5 & 8.2 & 8.0 & $\mathrm{n}$ & $n$ & $\mathrm{n}$ \\
\hline Spain & 1984 & 0.7 & 1.0 & 3.8 & $\mathrm{n}$ & $\mathrm{n}$ & $\mathrm{n}$ \\
\hline Sri Lanka & 1979 & 0.5 & 1.1 & 4.1 & $\mathrm{n}$ & $\mathrm{n}$ & $\mathrm{n}$ \\
\hline Syria & 1969 & 11.4 & -19.2 & 5.8 & $y$ & $y$ & $y$ \\
\hline Syria & 1974 & 5.2 & 17.1 & 4.8 & $n$ & $y$ & $\mathrm{n}$ \\
\hline Syria & 1989 & -10.0 & 6.3 & 4.4 & $n$ & $n$ & $\mathrm{n}$ \\
\hline Taiwan & 1961 & 4.0 & 4.6 & 7.1 & $\mathrm{n}$ & $\mathrm{n}$ & $\mathrm{n}$ \\
\hline Thailand & 1957 & 10.9 & -0.6 & 5.3 & $y$ & $y$ & $\mathrm{y}$ \\
\hline $\begin{array}{l}\text { Thailand } \\
\text { Trinidad }\end{array}$ & 1986 & 3.0 & 7.2 & 8.1 & $\mathrm{n}$ & $\mathrm{n}$ & $\mathrm{n}$ \\
\hline \&Tobago & 1975 & 1.4 & 8.5 & 5.4 & $n$ & $\mathrm{n}$ & $n$ \\
\hline Tunisia & 1968 & 9.7 & 4.7 & 6.6 & $y$ & $y$ & $\mathrm{n}$ \\
\hline Uganda & 1977 & -0.8 & -6.3 & 4.0 & $y$ & $n$ & $y$ \\
\hline Uganda & 1989 & 1.3 & 5.2 & 3.6 & $\mathrm{n}$ & $\mathrm{n}$ & $\mathrm{n}$ \\
\hline United Kingdom & 1982 & 2.4 & 3.8 & 3.5 & $\mathrm{n}$ & $\mathrm{n}$ & $\mathrm{n}$ \\
\hline United States & 1961 & 0.4 & 4.7 & 3.9 & $\mathrm{n}$ & $\mathrm{n}$ & $\mathrm{n}$ \\
\hline Uruguay & 1974 & 1.8 & 5.0 & 4.0 & $\mathrm{n}$ & $\mathrm{n}$ & $\mathrm{n}$ \\
\hline Uruguay & 1989 & 0.1 & -0.9 & 3.8 & y & $\mathrm{n}$ & $\mathrm{y}$ \\
\hline Zimbabwe & 1964 & 5.6 & 10.1 & 7.2 & $\mathrm{n}$ & $\mathrm{n}$ & $\mathrm{n}$ \\
\hline
\end{tabular}

Notes: column (1) indicates the start of the acceleration; column (2) shows the rate of growth in the year preceding the acceleration; column (3) contains the growth rate at the start of the acceleration; column (4) presents the average growth rate during the episode; column (5) indicates whether the growth before the start of the acceleration exceeds the growth rate at the start of the episode $(y=y e s ; n=$ no); column (6) indicates whether the growth before the start of the acceleration exceeds the average growth rate of the episode; and column (7) shows whether there is a negative growth rate at the start of the episode. 
Table 2. Growth accelerations according to our filter

\begin{tabular}{|c|c|c|c|c|c|}
\hline Country & $\begin{array}{l}\text { (1) } \\
\text { Year }\end{array}$ & $\begin{array}{l}\text { Growth } \\
\text { before }\end{array}$ & $\begin{array}{c}\text { Growth } \\
\text { during }\end{array}$ & $\begin{array}{l}\text { Difference in } \\
\text { growth rate }\end{array}$ & $\begin{array}{c}\text { Difference in years } \\
\text { with HPR }\end{array}$ \\
\hline Algeria & 1975 & 2.1 & 4.2 & 2.1 & 0 \\
\hline Argentina & 1963 & 0.9 & 3.6 & 2.7 & 0 \\
\hline Argentina & 1990 & -3.1 & 6.1 & 9.2 & 0 \\
\hline Australia & 1961 & 1.5 & 3.8 & 2.3 & 0 \\
\hline Belgium & 1958 & 2.4 & 4.7 & 2.3 & 1 \\
\hline Botswana & 1970 & 3.3 & 11.4 & 8.1 & 1 \\
\hline Brazil & 1966 & 3.1 & 7.2 & 4.1 & 1 \\
\hline Cameroon & 1972 & -0.6 & 5.3 & 5.9 & 0 \\
\hline Canada & 1961 & 1.0 & 3.8 & 2.8 & 1 \\
\hline Chad & 1974 & -1.5 & 7.3 & 8.8 & 1 \\
\hline Chile & 1983 & 1.7 & 4.2 & 2.5 & 3 \\
\hline Chile & 1988 & 1.0 & 5.8 & 4.8 & ni5 \\
\hline China & 1976 & 2.0 & 5.3 & 3.4 & 2 \\
\hline China & 1981 & 3.5 & 6.5 & 3.0 & ni5 \\
\hline China & 1989 & 5.2 & 8.7 & 3.5 & 1 \\
\hline Colombia & 1967 & 1.6 & 4.0 & 2.4 & 0 \\
\hline Congo Rep. & 1969 & 0.9 & 5.4 & 4.5 & 0 \\
\hline Congo Rep. & 1977 & 3.8 & 8.7 & 4.9 & 1 \\
\hline Denmark & 1958 & 2.2 & 5.2 & 3.0 & 1 \\
\hline Dominican Rep. & 1968 & -0.2 & 6.5 & 6.6 & 1 \\
\hline Dominican Rep. & 1991 & 0.4 & 5.8 & 5.3 & 1 \\
\hline Ecuador & 1966 & 1.3 & 4.6 & 3.3 & 4 \\
\hline Ecuador & 1971 & 1.6 & 7.7 & 6.1 & ni5 \\
\hline Egypt & 1975 & -1.1 & 5.5 & 6.7 & 1 \\
\hline Finland & 1958 & 2.7 & 5.0 & 2.2 & 0 \\
\hline Finland & 1968 & 2.8 & 5.3 & 2.4 & 1 \\
\hline Finland & 1993 & -0.4 & 4.4 & 4.8 & 1 \\
\hline Ghana & 1965 & -0.1 & 8.3 & 8.4 & 0 \\
\hline Guinea-Bissau & 1971 & -5.5 & 10.0 & 15.4 & 2 \\
\hline India & 1982 & 1.5 & 3.9 & 2.4 & 0 \\
\hline Indonesia & 1967 & -0.8 & 5.5 & 6.2 & 0 \\
\hline Indonesia & 1987 & 3.4 & 5.5 & 2.1 & 0 \\
\hline Ireland & 1957 & 1.5 & 3.8 & 2.4 & 1 \\
\hline Ireland & 1986 & 1.5 & 4.9 & 3.5 & 1 \\
\hline Ireland & 1993 & 4.9 & 8.2 & 3.2 & ni93 \\
\hline Israel & 1958 & 2.4 & 5.4 & 2.9 & 1 \\
\hline Israel & 1967 & 2.8 & 7.2 & 4.4 & 0 \\
\hline Japan & 1958 & 5.8 & 9.0 & 3.2 & 0 \\
\hline Jordan & 1971 & -3.1 & 6.0 & 9.1 & 2 \\
\hline Rep. Korea & 1960 & 1.9 & 4.9 & 3.0 & 2 \\
\hline Rep. Korea & 1965 & 2.6 & 7.4 & 4.8 & ni5 \\
\hline Rep. Korea & 1981 & 5.5 & 7.8 & 2.3 & 3 \\
\hline Lesotho & 1969 & 1.7 & 3.9 & 2.2 & 2 \\
\hline Malawi & 1970 & 1.5 & 3.9 & 2.5 & 0 \\
\hline Malaysia & 1971 & 3.0 & 5.0 & 2.1 & 1 \\
\hline Malaysia & 1986 & 2.3 & 5.5 & 3.2 & 2 \\
\hline
\end{tabular}




\begin{tabular}{|c|c|c|c|c|c|}
\hline Mali & 1993 & 0.2 & 3.7 & 3.6 & ni93 \\
\hline Mauritius & 1969 & -1.5 & 4.7 & 6.2 & 2 \\
\hline Mauritius & 1983 & 1.0 & 5.5 & 4.4 & 0 \\
\hline Morocco & 1957 & -0.9 & 7.8 & 8.7 & 1 \\
\hline New Zealand & 1958 & 2.1 & 4.1 & 2.0 & 1 \\
\hline Nicaragua & 1959 & 1.1 & 5.2 & 4.1 & 1 \\
\hline Nigeria & 1957 & 1.2 & 4.3 & 3.0 & 0 \\
\hline Nigeria & 1968 & -3.4 & 4.6 & 8.0 & 1 \\
\hline Norway & 1991 & 1.4 & 3.6 & 2.2 & 0 \\
\hline Pakistan & 1960 & -1.8 & 4.3 & 6.0 & 2 \\
\hline Pakistan & 1965 & 0.7 & 3.5 & 2.9 & ni5 \\
\hline Pakistan & 1977 & 1.6 & 4.4 & 2.7 & 2 \\
\hline Panama & 1959 & 1.5 & 5.4 & 3.9 & 0 \\
\hline Panama & 1976 & 1.9 & 5.3 & 3.4 & 1 \\
\hline Paraguay & 1973 & 2.6 & 5.9 & 3.3 & 1 \\
\hline Peru & 1959 & 0.8 & 5.2 & 4.4 & 0 \\
\hline Portugal & 1984 & 1.6 & 5.6 & 4.0 & 1 \\
\hline Romania & 1980 & 0.6 & 14.5 & 13.8 & 1 \\
\hline Rwanda & 1975 & 0.7 & 4.0 & 3.3 & 0 \\
\hline Singapore & 1967 & 7.0 & 10.6 & 3.6 & 2 \\
\hline Spain & 1959 & 4.4 & 8.0 & 3.5 & 0 \\
\hline Spain & 1984 & 0.1 & 3.8 & 3.7 & 0 \\
\hline Sri Lanka & 1979 & 1.9 & 4.1 & 2.2 & 0 \\
\hline Syria & 1970 & -0.3 & 5.2 & 5.5 & 1 \\
\hline Syria & 1989 & -2.9 & 4.4 & 7.3 & 0 \\
\hline Taiwan & 1960 & 3.3 & 6.8 & 3.4 & 1 \\
\hline Taiwan & 1966 & 6.1 & 8.6 & 2.5 & ni5 \\
\hline Thailand & 1958 & -0.9 & 5.4 & 6.3 & 1 \\
\hline Thailand & 1983 & 4.3 & 6.6 & 2.3 & 3 \\
\hline Trinidad \&Tobago & 1971 & 2.1 & 4.8 & 2.7 & 4 \\
\hline Tunisia & 1969 & 2.5 & 6.4 & 3.8 & 1 \\
\hline Tunisia & 1993 & 1.6 & 3.7 & 2.1 & ni93 \\
\hline Uganda & 1989 & -0.8 & 3.6 & 4.4 & 0 \\
\hline United Kingdom & 1982 & 1.1 & 3.5 & 2.5 & 0 \\
\hline United States & 1961 & 0.9 & 3.9 & 3.0 & 1 \\
\hline Uruguay & 1974 & 1.5 & 4.0 & 2.6 & 0 \\
\hline Zimbabwe & 1963 & 0.2 & 6.6 & 6.4 & 1 \\
\hline Zimbabwe & 1968 & 3.5 & 6.5 & 3.0 & ni5 \\
\hline
\end{tabular}

Notes: column (1) indicates the start of the acceleration; column (2) shows the rate of growth in the 8 years preceding the acceleration; column (3) presents the average growth rate during the episode; column (4) presents the difference between column (2) and (3); and column (5) shows the differences between our filter and that of Hausmann et al. (2005). Ni5 denotes that the fact that we identify this acceleration, whilst Hausmann et al. (2005) do not identify this acceleration. This is due to a timing difference of the first acceleration and the possibility of an acceleration from the $5^{\text {th }}$ year onwards after the first acceleration. Ni93 denotes accelerations starting in 1993. These are not included by Hausmann et al. (2005). 
Table 3. Estimation results: baseline model

\begin{tabular}{|c|c|c|c|c|c|c|c|c|}
\hline \multirow[t]{2}{*}{ Dependent variable: timing of a growth acceleration } & \multicolumn{3}{|c|}{ all episodes } & \multicolumn{5}{|c|}{ post crises periods excluded } \\
\hline & $(1)$ & $(2)$ & $(3)$ & $(4)$ & $(5)$ & $(6)$ & $(7)$ & $(8)$ \\
\hline Trend & $\begin{array}{c}-0.066 \\
(7.72)^{\star \star \star}\end{array}$ & $\begin{array}{c}-0.052 \\
(5.41)^{\star \star \star}\end{array}$ & $\begin{array}{c}-0.056 \\
(6.08)^{\star \star \star}\end{array}$ & $\begin{array}{c}-0.062 \\
(7.14)^{\star \star \star}\end{array}$ & $\begin{array}{c}-0.067 \\
(7.25)^{\star \star \star}\end{array}$ & $\begin{array}{c}-0.049 \\
(4.67)^{\star \star \star}\end{array}$ & $\begin{array}{c}-0.051 \\
(5.12)^{\star \star \star}\end{array}$ & $\begin{array}{c}-0.063 \\
(6.65)^{\star \star \star}\end{array}$ \\
\hline Economic Reform & $\begin{array}{c}0.811 \\
(2.85)^{\star \star \star}\end{array}$ & $\begin{array}{c}0.724 \\
(2.53)^{\star \star}\end{array}$ & $\begin{array}{c}0.752 \\
(2.66)^{\star \star \star}\end{array}$ & $\begin{array}{c}0.803 \\
(2.82)^{\star \star \star}\end{array}$ & $\begin{array}{c}1.061 \\
(3.47)^{\star \star \star}\end{array}$ & $\begin{array}{c}0.967 \\
(3.15)^{\star \star \star}\end{array}$ & $\begin{array}{c}0.982 \\
(3.22)^{\star \star \star}\end{array}$ & $\begin{array}{c}1.052 \\
(3.44)^{\star \star \star}\end{array}$ \\
\hline Regime change & $\begin{array}{r}-0.117 \\
(0.47)\end{array}$ & $\begin{array}{l}-0.491 \\
(1.82)^{\star}\end{array}$ & & & $\begin{array}{l}0.255 \\
(0.96)\end{array}$ & $\begin{array}{r}-0.257 \\
(0.89)\end{array}$ & & \\
\hline Regime duration & & $\begin{array}{c}-0.037 \\
(3.08)^{\star \star \star}\end{array}$ & $\begin{array}{c}-0.027 \\
(2.53)^{\star \star}\end{array}$ & & & $\begin{array}{c}-0.048 \\
(3.55)^{\star \star \star}\end{array}$ & $\begin{array}{c}-0.042 \\
(3.59)^{\star \star \star}\end{array}$ & \\
\hline Positive regime change & & & & $\begin{array}{l}-0.645 \\
(1.92)^{\star}\end{array}$ & & & & $\begin{array}{l}-0.248 \\
(0.72)\end{array}$ \\
\hline Negative regime change & & & & $\begin{array}{l}0.398 \\
(1.30)\end{array}$ & & & & $\begin{array}{c}0.824 \\
(2.45)^{\star \star}\end{array}$ \\
\hline Pseudo R-squared & 0.08 & 0.09 & 0.09 & 0.09 & 0.09 & 0.11 & 0.11 & 0.10 \\
\hline Observations & 1235 & 1235 & 1238 & 1235 & 1059 & 1059 & 1061 & 1059 \\
\hline Countries & 46 & 46 & 46 & 46 & 40 & 40 & 40 & 40 \\
\hline Hausman test, prob>Chi^2 & 0.0028 & 0.0002 & 0.0039 & 0.0067 & 0.0129 & 0.0001 & 0.0001 & 0.0097 \\
\hline
\end{tabular}

Absolute value of $z$ statistics in parentheses

* significant at 10\%; ${ }^{* *}$ significant at $5 \%$; *** significant at $1 \%$ 
Table 4. Sensitivity analysis

\begin{tabular}{|c|c|c|c|c|c|c|c|c|c|}
\hline \multirow[t]{2}{*}{$\begin{array}{l}\text { Dependent variable: timing of a growth } \\
\text { acceleration }\end{array}$} & \multicolumn{2}{|c|}{$\begin{array}{l}\text { Regime changes } \\
\text { according to Vanhanen }\end{array}$} & \multicolumn{2}{|c|}{$\begin{array}{l}\text { Regime changes according } \\
\text { to Przworski et al. }\end{array}$} & \multirow{2}{*}{$\begin{array}{l}\text { 2year filter } \\
\text { (5) }\end{array}$} & \multicolumn{4}{|c|}{ Various control variables added } \\
\hline & (1) & (2) & (3) & (4) & & (6) & (7) & $(8)$ & $(9)$ \\
\hline Trend & $\begin{array}{l}-0.054 \\
(5.64)^{\star \star \star}\end{array}$ & $\begin{array}{l}-0.049 \\
(5.01)^{\star \star \star}\end{array}$ & $\begin{array}{l}-0.053 \\
(5.44)^{\star * \star}\end{array}$ & $\begin{array}{l}-0.049 \\
(4.98)^{\star \star \star}\end{array}$ & $\begin{array}{l}-0.036 \\
(3.47)^{\star \star \star}\end{array}$ & $\begin{array}{l}0.012 \\
(0.65)\end{array}$ & $\begin{array}{l}-0.036 \\
(2.94)^{\star \star \star}\end{array}$ & $\begin{array}{l}-0.032 \\
(2.80)^{\star \star \star}\end{array}$ & $\begin{array}{l}-0.039 \\
(3.45)^{\star \star \star}\end{array}$ \\
\hline Economic reform & $\begin{array}{l}0.726 \\
(2.56)^{\star \star}\end{array}$ & $\begin{array}{l}0.717 \\
(2.52)^{\star \star}\end{array}$ & $\begin{array}{l}0.589 \\
(1.99)^{\star \star}\end{array}$ & $\begin{array}{l}0.536 \\
(1.81)^{\star}\end{array}$ & $\begin{array}{l}0.356 \\
(1.12)\end{array}$ & $\begin{array}{l}0.101 \\
(0.25)\end{array}$ & $\begin{array}{l}0.434 \\
(1.29)\end{array}$ & $\begin{array}{l}0.687 \\
(2.13)^{\star \star}\end{array}$ & $\begin{array}{l}0.725 \\
(2.26)^{\star \star}\end{array}$ \\
\hline Regime change & $\begin{array}{l}0.064 \\
(0.23)\end{array}$ & & $\begin{array}{l}0.241 \\
(0.86)\end{array}$ & & & & & & \\
\hline DURABLE & $\begin{array}{l}-0.028 \\
(2.58)^{\star \star \star}\end{array}$ & $\begin{array}{l}-0.031 \\
(2.80)^{\star \star \star}\end{array}$ & $\begin{array}{l}-0.026 \\
(2.27)^{\star \star}\end{array}$ & $\begin{array}{l}-0.029 \\
(2.47)^{\star \star}\end{array}$ & $\begin{array}{l}-0.044 \\
(3.54)^{\star \star \star}\end{array}$ & $\begin{array}{l}-0.053 \\
(2.60)^{\star \star \star}\end{array}$ & $\begin{array}{l}-0.056 \\
(4.09)^{\star \star \star}\end{array}$ & $\begin{array}{l}-0.057 \\
(4.24)^{\star \star \star}\end{array}$ & $\begin{array}{l}-0.050 \\
(3.79)^{\star \star \star}\end{array}$ \\
\hline Positive regime change & & $\begin{array}{l}-0.763 \\
(1.91)^{\star}\end{array}$ & & $\begin{array}{l}-0.205 \\
(0.56)\end{array}$ & $\begin{array}{l}-1.234 \\
(3.45)^{\star \star \star}\end{array}$ & $\begin{array}{l}-1.879 \\
(3.39)^{\star \star \star}\end{array}$ & $\begin{array}{l}-1.958 \\
(4.03)^{\star \star \star}\end{array}$ & $\begin{array}{l}-1.796 \\
(4.10)^{\star \star \star}\end{array}$ & $\begin{array}{l}-1.784 \\
(4.04)^{\star \star \star}\end{array}$ \\
\hline Negative regime change & & $\begin{array}{l}0.727 \\
(2.26)^{\star \star}\end{array}$ & & $\begin{array}{l}0.682 \\
(1.99)^{\star \star}\end{array}$ & $\begin{array}{l}0.195 \\
(0.64)\end{array}$ & $\begin{array}{l}0.226 \\
(0.52)\end{array}$ & $\begin{array}{l}-0.008 \\
(0.02)\end{array}$ & $\begin{array}{l}-0.052 \\
(0.16)\end{array}$ & $\begin{array}{l}-0.047 \\
(0.14)\end{array}$ \\
\hline Terms of trade & & & & & & $\begin{array}{l}0.014 \\
(0.03)\end{array}$ & & & \\
\hline Civil war & & & & & & & & & $\begin{array}{l}1.092 \\
(1.92)^{\star}\end{array}$ \\
\hline End of war & & & & & & & & & $\begin{array}{l}-0.341 \\
(0.98)\end{array}$ \\
\hline Leader death & & & & & & & & $\begin{array}{l}-0.267 \\
(0.44)\end{array}$ & \\
\hline Tenure death & & & & & & & & $\begin{array}{l}-0.097 \\
(1.29)\end{array}$ & \\
\hline Financial liberalization & & & & & & & $\begin{array}{l}0.588 \\
(1.24)\end{array}$ & & \\
\hline Observations & 1215 & 1215 & 1208 & 1208 & 1239 & 559 & 1035 & 1121 & 1121 \\
\hline Countries & 45 & 45 & 45 & 45 & 46 & 29 & 42 & 42 & 42 \\
\hline Pseudo R-squared & 0.08 & 0.10 & 0.08 & 0.08 & 0.09 & 0.05 & 0.11 & 0.12 & 0.11 \\
\hline
\end{tabular}

Absolute value of $z$ statistics in parentheses

* significant at 10\%; ** significant at 5\%; *** significant at $1 \%$ 
Figure 1. Identifying growth accelerations

Botswana

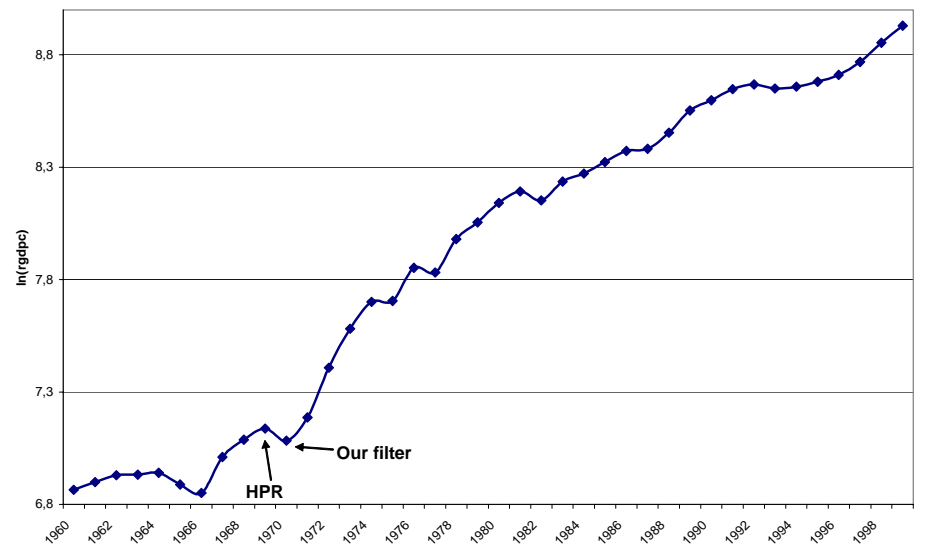

Chile

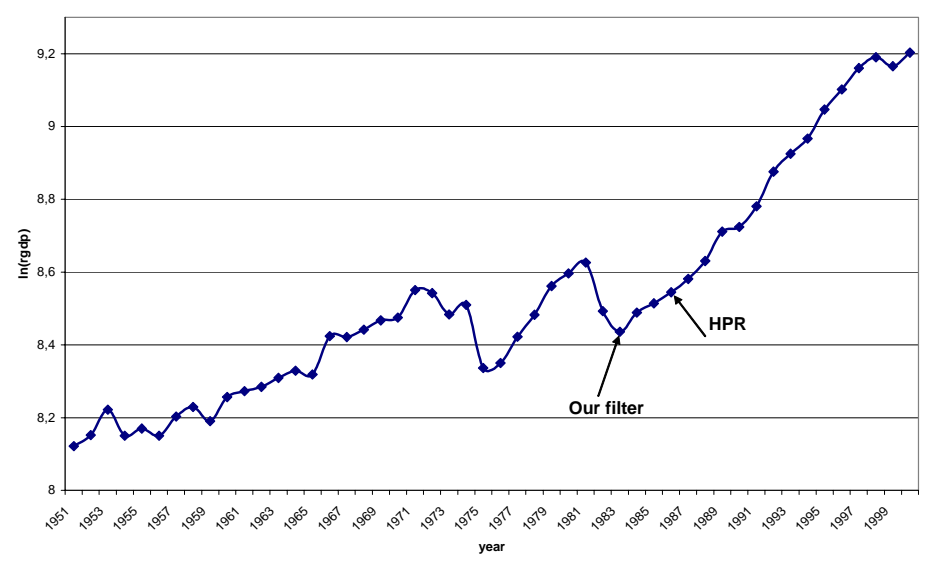

Mali

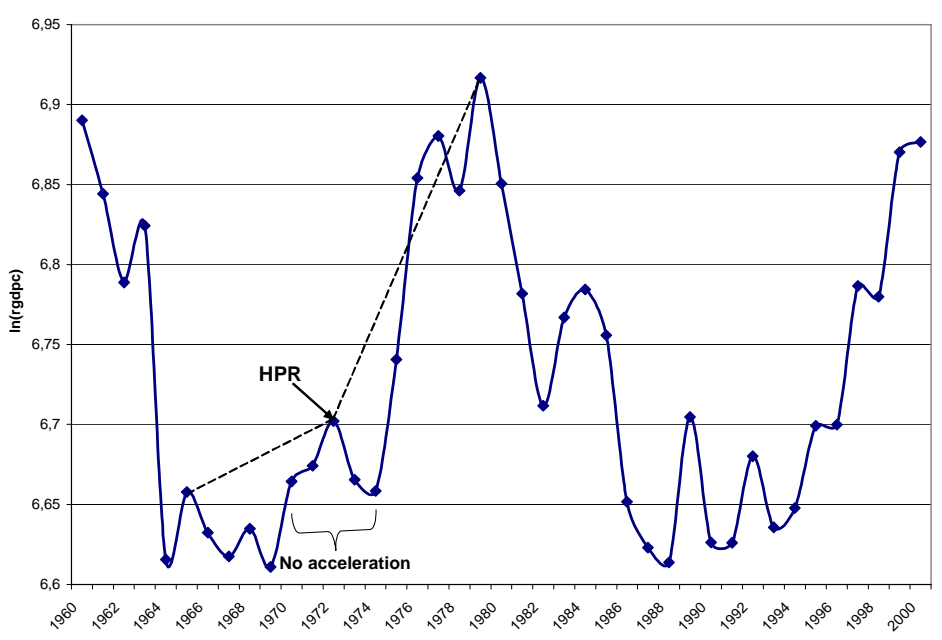


Figure 2. Growth accelerations over time, 1957-1993

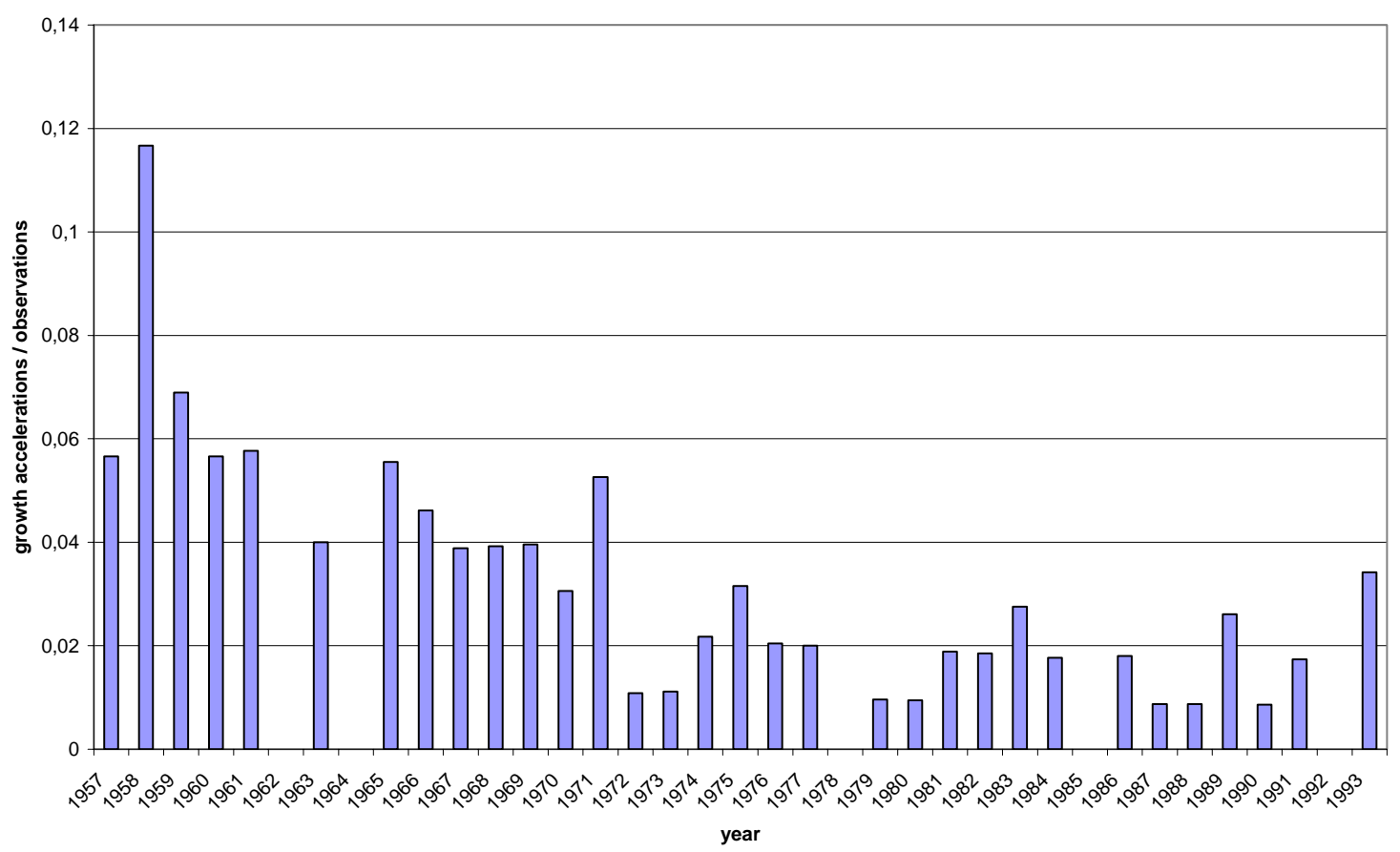

Note: the figure shows the number of growth accelerations per year. 


\section{CESifo Working Paper Series}

(for full list see www.cesifo-group.de)

1844 Eytan Sheshinski, Differentiated Annuities in a Pooling Equilibrium, November 2006

1845 Marc Suhrcke and Dieter Urban, Are Cardiovascular Diseases Bad for Economic Growth?, November 2006

1846 Sam Bucovetsky and Andreas Haufler, Preferential Tax Regimes with Asymmetric Countries, November 2006

1847 Luca Anderlini, Leonardo Felli and Andrew Postlewaite, Should Courts always Enforce what Contracting Parties Write?, November 2006

1848 Katharina Sailer, Searching the eBay Marketplace, November 2006

1849 Paul De Grauwe and Pablo Rovira Kaltwasser, A Behavioral Finance Model of the Exchange Rate with Many Forecasting Rules, November 2006

1850 Doina Maria Radulescu and Michael Stimmelmayr, ACE vs. CBIT: Which is Better for Investment and Welfare?, November 2006

1851 Guglielmo Maria Caporale and Mario Cerrato, Black Market and Official Exchange Rates: Long-Run Equilibrium and Short-Run Dynamics, November 2006

1852 Luca Anderlini, Leonardo Felli and Andrew Postlewaite, Active Courts and Menu Contracts, November 2006

1853 Andreas Haufler, Alexander Klemm and Guttorm Schjelderup, Economic Integration and Redistributive Taxation: A Simple Model with Ambiguous Results, November 2006

1854 S. Brock Blomberg, Thomas DeLeire and Gregory D. Hess, The (After) Life-Cycle Theory of Religious Contributions, November 2006

1855 Albert Solé-Ollé and Pilar Sorribas-Navarro, The Effects of Partisan Alignment on the Allocation of Intergovernmental Transfers. Differences-in-Differences Estimates for Spain, November 2006

1856 Biswa N. Bhattacharyay, Understanding the Latest Wave and Future Shape of Regional Trade and Cooperation Agreements in Asia, November 2006

1857 Matz Dahlberg, Eva Mörk, Jørn Rattsø and Hanna Ågren, Using a Discontinuous Grant to Identify the Effect of Grants on Local Taxes and Spending, November 2006

1858 Ernesto Crivelli and Klaas Staal, Size and Soft Budget Constraints, November 2006 
1859 Jens Brøchner, Jesper Jensen, Patrik Svensson and Peter Birch Sørensen, The Dilemmas of Tax Coordination in the Enlarged European Union, November 2006

1860 Marcel Gérard, Reforming the Taxation of Multijurisdictional Enterprises in Europe, "Coopetition" in a Bottom-up Federation, November 2006

1861 Frank Blasch and Alfons J. Weichenrieder, When Taxation Changes the Course of the Year - Fiscal Year Adjustments and the German Tax Reform 2000/2001, November 2006

1862 Hans Jarle Kind, Tore Nilssen and Lars Sørgard, Competition for Viewers and Advertisers in a TV Oligopoly, November 2006

1863 Bart Cockx, Stéphane Robin and Christian Goebel, Income Support Policies for PartTime Workers: A Stepping-Stone to Regular Jobs? An Application to Young LongTerm Unemployed Women in Belgium, December 2006

1864 Sascha O. Becker and Marc-Andreas Muendler, The Effect of FDI on Job Separation, December 2006

1865 Christos Kotsogiannis and Robert Schwager, Fiscal Equalization and Yardstick Competition, December 2006

1866 Mikael Carlsson, Stefan Eriksson and Nils Gottfries, Testing Theories of Job Creation: Does Supply Create Its Own Demand?, December 2006

1867 Jacques H. Drèze, Charles Figuières and Jean Hindriks, Voluntary Matching Grants Can Forestall Social Dumping, December 2006

1868 Thomas Eichner and Marco Runkel, Corporate Income Taxation of Multinationals and Unemployment, December 2006

1869 Balázs Égert, Central Bank Interventions, Communication and Interest Rate Policy in Emerging European Economies, December 2006

1870 John Geweke, Joel Horowitz and M. Hashem Pesaran, Econometrics: A Bird's Eye View, December 2006

1871 Hans Jarle Kind, Marko Koethenbuerger and Guttorm Schjelderup, Taxation in TwoSided Markets, December 2006

1872 Hans Gersbach and Bernhard Pachl, Cake Division by Majority Decision, December 2006

1873 Gunther Schnabl, The Evolution of the East Asian Currency Baskets - Still Undisclosed and Changing, December 2006

1874 Horst Raff and Michael J. Ryan, Firm-Specific Characteristics and the Timing of Foreign Direct Investment Projects, December 2006 
1875 Jukka Pirttilä and Håkan Selin, How Successful is the Dual Income Tax? Evidence from the Finnish Tax Reform of 1993, December 2006

1876 Agnieszka Stążka, Sources of Real Exchange Rate Fluctuations in Central and Eastern Europe - Temporary or Permanent?, December 2006

1877 Xavier Calsamiglia, Teresa Garcia-Milà and Therese J. McGuire, Why do Differences in the Degree of Fiscal Decentralization Endure?, December 2006

1878 Natacha Gilson, How to be Well Shod to Absorb Shocks? Shock Synchronization and Joining the Euro Zone, December 2006

1879 Scott Alan Carson, Modern Health Standards for Peoples of the Past: Biological Conditions by Race in the American South, 1873 - 1919, December 2006

1880 Peter Huber, Michael Pfaffermayr and Yvonne Wolfmayr, Are there Border Effects in the EU Wage Function?, December 2006

1881 Harry Flam and Håkan Nordström, Euro Effects on the Intensive and Extensive Margins of Trade, December 2006

1882 Panu Poutvaara and Mikael Priks, Hooliganism in the Shadow of the 9/11 Terrorist Attack and the Tsunami: Do Police Reduce Group Violence?, December 2006

1883 Ruud A. de Mooij and Gaëtan Nicodème, Corporate Tax Policy, Entrepreneurship and Incorporation in the EU, December 2006

1884 Johannes Becker and Clemens Fuest, Corporate Tax Policy and International Mergers and Acquisitions - Is the Tax Exemption System Superior?, January 2007

1885 Momi Dahan and Udi Nisan, The Effect of Benefits Level on Take-up Rates: Evidence from a Natural Experiment, January 2007

1886 José García-Solanes, Francisco I. Sancho-Portero and Fernando Torrejón-Flores, Beyond the Salassa-Samuelson Effect in some New Member States of the European Union, January 2007

1887 Peter Egger, Wolfgang Eggert and Hannes Winner, Saving Taxes Through Foreign Plant Ownership, January 2007

1888 Timothy J. Goodspeed and Andrew Haughwout, On the Optimal Design of Disaster Insurance in a Federation, January 2007

1889 Wim Groot, Henriëtte Maassen van den Brink and Bernard van Praag, The Compensating Income Variation of Social Capital, January 2007

1890 Bas Jacobs, Ruud A. de Mooij and Kees Folmer, Analyzing a Flat Income Tax in the Netherlands, January 2007 
1891 Hans Jarle Kind, Guttorm Schjelderup and Frank Stähler, Newspapers and Advertising: The Effects of Ad-Valorem Taxation under Duopoly, January 2007

1892 Erkki Koskela and Rune Stenbacka, Equilibrium Unemployment with Outsourcing under Labour Market Imperfections, January 2007

1893 Maarten Bosker, Steven Brakman, Harry Garretsen, Herman de Jong and Marc Schramm, The Development of Cities in Italy 1300 - 1861, January 2007

1894 Michel Beine, Oscar Bernal, Jean-Yves Gnabo and Christelle Lecourt, Intervention Policy of the BoJ: A Unified Approach, January 2007

1895 Robert S. Chirinko and Daniel J. Wilson, State Investment Tax Incentives: A Zero-Sum Game?, January 2007

1896 Theo S. Eicher and Oliver Roehn, Sources of the German Productivity Demise Tracing the Effects of Industry-Level ICT Investment, January 2007

1897 Helge Berger, Volker Nitsch and Tonny Lybek, Central Bank Boards around the World: Why does Membership Size Differ?, January 2007

1898 Gabriel Felbermayr and Wilhelm Kohler, Does WTO Membership Make a Difference at the Extensive Margin of World Trade?, January 2007

1899 Benno Torgler and Friedrich Schneider, The Impact of Tax Morale and Institutional Quality on the Shadow Economy, January 2007

1900 Tomer Blumkin and Efraim Sadka, On the Desirability of Taxing Charitable Contributions, January 2007

1901 Frederick van der Ploeg and Reinhilde Veugelers, Higher Education Reform and the Renewed Lisbon Strategy: Role of Member States and the European Commission, January 2007

1902 John Lewis, Hitting and Hoping? Meeting the Exchange Rate and Inflation Criteria during a Period of Nominal Convergence, January 2007

1903 Torben M. Andersen, The Scandinavian Model - Prospects and Challenges, January 2007

1904 Stephane Dees, Sean Holly, M. Hashem Pesaran and L. Vanessa Smith, Long Run Macroeconomic Relations in the Global Economy, January 2007

1905 Richard Jong-A-Pin and Jakob De Haan, Political Regime Change, Economic Reform and Growth Accelerations, January 2007 